\title{
Evaluation of Rainfall-Induced Landslides triggering using a multidisciplinary approach
}

\author{
Ivo Fustos ${ }^{1, *}$, Pablo Moreno-Yaeger ${ }^{2,3}$, Daniel Vasquez ${ }^{3}$, Bastian Morales ${ }^{3}$, \\ Antonieta Silva ${ }^{4}$, Elisa Ramirez ${ }^{3}$
}

Edited by

Juan Carlos Salcedo-Reyes

(salcedo.juan@javeriana.edu.co)

1. Department of Civil Engineering, Universidad de La Frontera,

Temuco-Chile

2. Department of Geoscience,

University of Wisconsin-Madison,

Wisconsin, USA

3. Departamento de Obras Civiles

y Geología, Universidad Católica de

Temuco, Temuco-Chile

4. Departamento de Ciencias Físicas,

Universidad de La Frontera,

Temuco-Chile.

*ivo.fustos@ufrontera.cl

Received: 20-05-2019

Accepted: 13-05-2020

Published on line: 27-08-2020

Citation: Fustos I, Moreno-Yaeger P, Vasquez D, Morales B, Silva A, Ramirez E. Evaluation of RainfallInduced Landslides triggering using a multidisciplinary approach, Universitas Scientiarum, 25 (2): 277-298, 2020.

doi: 10.11144/Javeriana.SC25-2.eorl

Funding:

ANID international grant 72200330.

Electronic supplementary material: N.A.

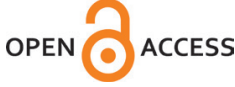

\begin{abstract}
In a large part of South America, slow landslides are triggered by extreme hydrometeorological conditions leading to, for instance, Rainfall-Induced Landslides - RILs. These RILs are common in urban areas and have a negative impact on the population and infrastructure development. Despite their importance, these events are little understood. We aimed at understanding the spatial distribution of RILs in the urban zone of Temuco, Chile $\left(38.8^{\circ} \mathrm{S}\right.$, $\left.72.6^{\circ} \mathrm{W}\right)$. The area has the typical hydrometeorological conditions of southern Chile. We conducted our assessment with a temporal analysis of shallow deformations, obtained by synthetic aperture radar interferometry (Sentinel $1 \mathrm{~A} / \mathrm{B})$. These shallow deformation rates were compared with satellite precipitation data (CHIRPS product) and electrical resistivity tomography (ERT). We identified active RIL-prone zones with deformation rates greater than $60 \mathrm{~mm}$ during the period 2014 to 2017, supporting theories of hydrometeorological control. Slow movements were observed in volcanic soils, suggesting the influence of their geotechnical characteristics. Our results can be extrapolated to the southern Andes $\left(35^{\circ} \mathrm{S}-43^{\circ} \mathrm{S}\right)$, where a large number of volcanic-sedimentary units are susceptible to RILs. Finally, integration of our multidisciplinary approach will facilitate understanding of the local RIL dynamics, allowing a better risk management to decision-makers in South American and other developing countries.
\end{abstract}

Keywords: InSAR Time-series; Rainfall-Induced Landslides.

\section{Introduction}

Rainfall-induced Landslides (RILs) cause serious damage to public infrastructure worldwide. These events usually cause losses and casualties in populations, due to the poor capacity of stakeholders to make adequate decisions [1]. Furthermore, the extent of damage caused by 
landslides is amplified by climate change [2]. Slow landslides provoked by hydrometeorological effects are becoming more and more frequent around the world and hinder a economic development [3]. The impacts of these phenomena vary considerably depending on local geological-geotechnical conditions and socio-economic vulnerability [4]. It is estimated that $14 \%$ of the economic losses and $0.53 \%$ of the deaths due to natural disasters are related with slow landslides [3]. For this reason, work related with these processes has been undertaken by the scientific community in recent years.

In developing countries, the lack of knowledge about these hazards worsens their impact [5]. Researchers have focused their efforts on improving the characterization and understanding of RILs, providing solid information to predict these events and to develop protection and mitigation measures [6]. Comprehensive analyses of the factors triggering RILs have been done via different methodologies for modelling of spatial-temporal processes [7].

Hillslope deformation, related to RILs with slow movement (RIL-SM) is research topic due to lack of understanding of the mechanisms involved at mid-latitudes in developing countries. Preliminary reports for America predict a decrease in precipitation, with periods of intense rainfall [8]. Here, changes in the intensity and duration of rainfall will overload hillslopes, triggering RIL events [9]. An example was reported in California, where slow-moving landslides were sensitive to large changes in annual precipitation [10]. In South America, the association between drought and RILs is relevant as well, for instance, in Chile where a current megadrought event is taking place [11]. The hydrometeorological information gap constrains informed predictions of RILs in regions of south-central Chile that have a previous record of these events. The knowledge is limited about current conditions in hillslopes that could be affected by RIL; the spatial and temporal distribution of RIL needs to be addressed from geophysical, geological, and hydrometeorological perspectives.

Water is one of the most important factors associated with slow landslides, the majority of which occur after periods of precipitation [3]. Water exerts pore-pressure on soil particles, diminishing the effective tension and consequently the shear resistance of the hillslope. This is based on the principle of effective tensions, formulated by Terzaghi (1943) [12], which states that soil behavior is governed by effective tensions. Another important factor is the type and composition of the substrate. If the effective soil porosity (percentage of pores interconnected as a proportion of total volume) is low, water will not percolate into the substrate, leading to sliding of the material in sub-superficial levels. Effective tension is commonly countered 
by creating water circulation channels, but there is inadequate analysis of substrate, because it depends on the soil and its origins [13]. In particular, the south-central zone of Chile has suffered extensive forest intervention with introduced tree species. This practice leads to physicochemical weathering of the soil towards the clay group of minerals, drastically diminishing its effective porosity [14].

In South America, hydrometeorological factors play a determining role in slow landslides through the intensity, duration, and distribution of precipitation. Low-intensity precipitations over prolonged periods and high-intensity precipitations in short periods can trigger slow landslide events in areas where conditions are favorable. In the context of climate change, preliminary works exist on a regional scale [15]. They show the little understanding in South America to these phenomena, despite the frequency with which they occur.

RIL events near the equator have been evaluated in detail [15]. However, RIL in mid-latitudes have not been studied in the light of forcing changes driven by climate factors such as precipitation regimes. This limits the prediction of their occurrence. Furthermore, there is a need to develop a methodological platform to allow evaluation of slow landslides to be extended through the inclusion of remote and in situ data. Sepúlveda \& Petley [15] have addressed this problem, emphasizing that better understanding of RIL could significantly reduce the losses that they cause. Currently, remote sensing and in situ measurements allows the understanding and evaluation of the qualitative relationship between slow movement rates and the extent of damage to structures, using multisensor data. However, these approaches alone cannot lead to a solid understanding of RIL events, which would enable us to determine the susceptibility of buildings to damage [16], and would keep people and structures safe.

A multidisciplinary approach to RIL monitoring would allow us to measure deformation rates. However, surface deformation monitoring by remote sensing is an open question in South America, due to RIL size [17]. Furthermore, obtaining in situ measurements without drilling is not feasible in most of South America. In the present study, we evaluated an active RIL zone using an interdisciplinary methodology in order to understand and analyze the role of the hydrometeorological and geological conditions in generating RIL, and thus develop a predictive tool. Surface deformation rates associated with RIL events were evaluated using remote sensing techniques. We integrated geotechnical, geophysical, and geological data to create a scheme which will enable us to understand and quantify a RIL event in central-south Chile. 


\section{Materials and Methods}

\section{Study area}

The study area is located close to Temuco $\left(38.72^{\circ} \mathrm{S}, 72.59^{\circ} \mathrm{W}\right)$, the largest city in the Araucanía Region of Chile (Fig. 1). The principal formation in the area is the Pilmahue Formation (OMp) [5]. We recognize two members of this formation with andesitic lavas, sub-volcanic bodies, feeders (stocks, dykes) and minor sedimentary intercalation [5]. The area has undergone intense alterations, making proper geochemical characterisation impossible; however, geochronological and stratigraphic analyses indicate that the geological unit dates to $30 \mathrm{Ma}$ [16]. Finally, the area is strongly dominated by the Lanalhue Fault Zone (LFZ) with a NW trend.

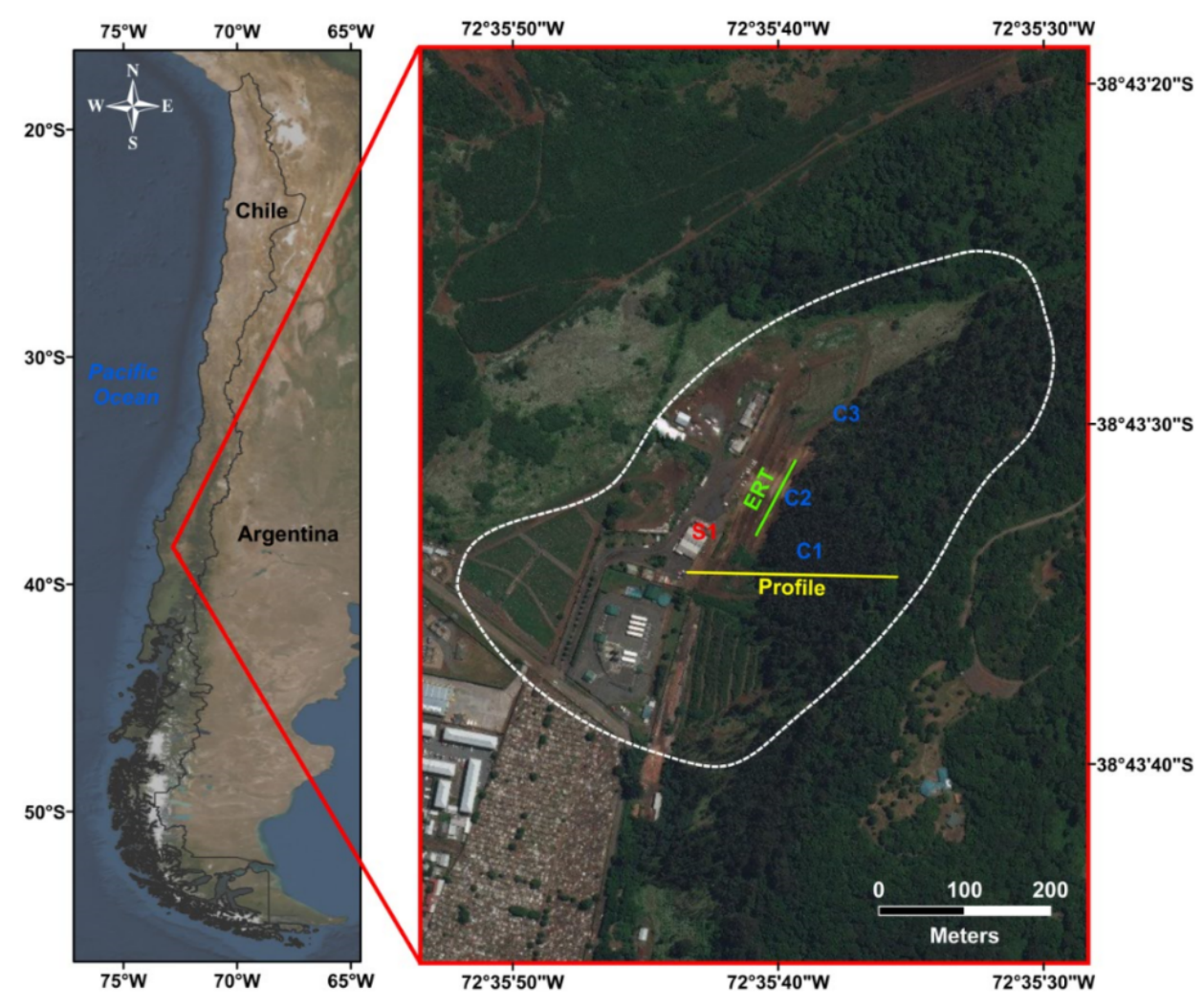

Figure 1. Location of the study area. The slow movement landslide of interest is delimited with a white line. The ERT point is where the electrical resistivity tomography equipment is placed. C1, C2, and C3 correspond to geotechnical soundings 1, 2 and 3 respectively. ${ }^{d}$ Degenerate sites are labelled in bold and underlined 
The climate is temperate with Mediterranean influence (Cfsb) and rainy winters. Mean temperatures fluctuate between $17.2^{\circ} \mathrm{C}$ (January) and $7.6^{\circ} \mathrm{C}$ (July), with an annual mean approximately of $12^{\circ} \mathrm{C}$. Precipitations occur all year round, with totals ranging between $1000 \mathrm{~mm}$ and $1500 \mathrm{~mm}$, depending on the impact of the ENSO cycle. The area has experienced a severe drought since 2008, which has reduced sub-surface water availability, average soil moisture, and the hydrogeological dynamic.

\section{Geophysical and geotechnical assessments}

We assessed the geophysical variables of the studied area, conducting a concept test in an active RIL zone by integrating different techniques to evaluate the compositional distribution of the hillslope, the geotechnical properties that make it unstable, and the superficial deformation that it suffers when modulated by local precipitation.

The geotechnical properties of the soil enabled us to assess the predisposition of the area to RIL. The geotechnical profile was analyzed using available 3-hole data at $15 \mathrm{~m}$. Sample analysis was mainly focused on a stratigraphic analysis, complete classification, direct shear test, and unconfined geotechnical test. The location of the soundings was generated from a preliminary background. This information was used to establish the soil's rheology and its first order predisposition to RILs.

Today, the use of non-invasive techniques has enabled us to understand the internal geometry of hillslopes [18]. Among existing techniques, electrical resistivity tomography (ERT) allows the identification of compositional changes from lateral and vertical variations in the resistivity of the soil [3]. We therefore carried out an ERT geophysical survey, using a dipole-dipole scheme to complement the geotechnical information obtained. Dipole-dipole works with a current injection (I) in the first dipole; the electrical field induced in the second dipole is read from the potential difference $(\mathrm{dV})$ at the second dipole. The ERT profile was carried out using 19 electrodes with a six-meter spacing $(\mathrm{dx})$. The field data allowed us to calculate an apparent resistivity model $\left(\rho_{a}\right)$ from the spacing of the dipoles and the current/voltage values measured (Eq 1). The apparent resistivity model was inverted using ResInv2D code with the least squares technique. The results were compared with different values of soil resistivity to establish composition profiles [12] using and apparent resistivity value. We define the resitivity value as:

$$
\rho_{a}=\pi n(n+1)(n+2) d x \frac{d V}{I}
$$


where $\mathrm{n}$ is the spacing ratio between the nearest electrodes for injection and measurement of the potential difference [18]. To carry out the dipole-dipole method of all the electrodes needed were placed at equal distances along the profile line.

\section{Geological assessments}

We carried out in-depth fieldwork to characterize the type of rock, the soil produced by edaphological processes, the presence or absence of cortical structures like faults and lineaments, and land use over recent decades. Moreover, rock and soil samples were taken and macroscopic descriptions were prepared. This information was complemented with national geological cartography provided by the Chilean Geological and Mining Survey (SERNAGEOMIN) through the geological map of the area [19]. We integrate in situ and remote sensing data available. In situ techniques allow visual and instrumental identification of RIL [19]. In addition, geophysical [20] and classical geotechnical prospecting were carried out to estimate the subsoil geometry and composition.

\section{Remote sensing}

We studied the surface deformation of the study area through the analysis of synthetic aperture radar (SAR) time-series data [21]. We recovered 22 acquisitions in SLC format from the Sentinel $1 \mathrm{~A}$ and Sentinel $1 \mathrm{~B}$ missions, from the European Union's Copernicus Programme (path 83/frame 720). We conducted an interferometric analysis out of the SAR data using the GMTSAR tool [22], leaving the acquisition to minimize the perpendicular baseline and temporal baseline values as the master image (2014-10-23) and the rest of the acquisitions as slaves.

InSAR has proved to be a powerful tool for the study of slow landslides, enabling the identification of the type of landslide and its variation in space and time in various case studies [3]. Because the InSAR methodology is extremely sensitive to low coherence values, which depend on the radar band used [23], interferograms with low coherence values were discarded. The speckle noise effect was reduced using a low-pass filter. We included interferograms with temporal baselines lower than 190 days [22]. In InSAR processing, the ambiguity error can be misinterpreted as a deformation process [24], we therefore included interferograms with perpendicular baseline less than $1,500 \mathrm{~m}$. Finally, the interferograms were inverted into a time-series using the Small Baseline Subset (SBAS) method. SBAS allows the generation of high-quality temporal deformation series and deformation velocity maps. It is based on interferograms with small perpendicular 
baselines. The capacity of SBAS to detect and investigate superficial deformation phenomena has been shown in cases of slow landslides [25]. Sources of uncertainty associated with tropospheric artefacts were quantified using global climate models [26].

Precipitation data were incorporated into the study to evaluate the hydrometeorological conditions under which the deformations occurred using Climate Hazards Group InfraRed Precipitation with Station (CHIRPS) data. This allows to obtain an high-resolution and long-term precipitation estimates, based on infrared observations corrected in situ by the authors using meteorological stations [27]. CHIRPS data use a new procedure for integrating information, incorporating the spatial correlation structure of the CCD estimates, to assign interpolation weights. Finally, we compared and associated deformation patterns from InSar [28] with satellite precipitation data. In Chile, satellite precipitation products only use CHIRPS data in the south-central area because of the scope of their agreement with meteorological stations [29].

\section{Results}

\section{Geophysics and Geotechnics}

We identified different soil types via in situ measurements associated with lithological composition. The soils identified were composed of clays and silts with different degrees of compressibility. Laboratory results revealed soils with a wide variation in soil moisture and plasticity (Table 1). We identified two juxtaposed units from geotechnical criteria; the lower unit representing rocks with slight chemical degradation, and the upper unit a highly weathered soil, divided into two subsoils classified as $\mathrm{CH}$ and ML (USCS). The average geomechanical conceptual model based on the representative profile is shown in Fig. 1.

Two horizons were observed, $\mathrm{H} 1$ and $\mathrm{H} 2$; $\mathrm{H} 2$ was divided further into $\mathrm{H} 2 \mathrm{a}$ and $\mathrm{H} 2 \mathrm{~b}$ because of the intense weathering. The horizon $\mathrm{H} 1$ contained saturated clays of a reddish-brown color, with soft consistency, high plasticity, a cracked homogeneous structure, and lack of organic matter. The horizon $\mathrm{H} 2 \mathrm{a}$ was a light brown silt with orange tones, high humidity, medium consistency, low plasticity, homogeneous structure and crumb, and lack of matter. The horizon $\mathrm{H} 2 \mathrm{~b}$ consisted of a greyish yellow rock with medium humidity, firm consistency, and high cementation. 
Table 1. Average Stratigraphic Model

\begin{tabular}{lcl}
\hline $\begin{array}{c}\text { Geotechnical } \\
\text { Unit }\end{array}$ & \multicolumn{1}{c}{ Depth } & \multicolumn{1}{c}{ Properties } \\
\hline H1 $(\mathrm{CH})$ & $0.00-2.00(\mathrm{~m})$ & $\mathrm{c}=3.92(\mathrm{MPa}), \varnothing=22.3^{\circ}, S_{u}=12.7$ \\
H2A (ML) & $2.00-3.00(\mathrm{~m})$ & $\begin{array}{l}(\mathrm{MPa}), \gamma=1.34\left(\mathrm{ton} / \mathrm{m}^{3}\right) \\
\mathrm{c}=29.4(\mathrm{MPa}), \varnothing=35^{\circ}, S_{u}=66.7\end{array}$ \\
H2B (ML) & $3.00-15.00(\mathrm{~m}) \begin{array}{l}(\mathrm{MPa}), \gamma=1.50\left(\text { ton } / \mathrm{m}^{3}\right) \\
\text { The structure is homogeneous. }\end{array}$ \\
\hline
\end{tabular}

Considering the soil types and the long-term stability conditions, consolidated, drained direct shear resistance tests were carried out in undisturbed samples extracted by ASTM criteria [30]. During sample extraction (June, 2018), we noted that shallow deformation was accompanied by small-scale, local, rainfall-induced landslides (less than $10 \mathrm{~m}^{2}$ ). These processes are generally found in foothills and correspond to flow-type and rotational translations according to the official classification [2].

\section{Geological assessments}

Our geological mapping results revealed the presence of surface structures related to the Pilmahue Formation dating to the Miocene, ca. $30 \mathrm{Ma}$ ([31] and references therein). The soil in the study area resulted both from pedogenesis of a volcano-sedimentary formation dating to the Miocene (Pilmahue Formation) and the physicochemical weathering produced by introduced radiata pines. Fig. 2 shows the dike-like subvolcanic bodies related to the Pilmahue Formation. The results were consistent with ERT data showing a moderately resistive body underlying layer $\mathrm{H} 2$ (Fig. 2 and Table 1). The resistivity of this underground body ranged from 50 to $300 \mathrm{~m}$ in $\mathrm{H} 2$.

Drilling results showed that the $\mathrm{H} 2$ horizon was divided into two layers, evidenced by resistivity changes. The resistivity of layer $\mathrm{H} 2 \mathrm{a}$ ranged from 50 to $132 \mathrm{~m}$, associated with a highly weathered volcanic body. The ERT results suggest the presence of a dehydrated body with resistivity between 132 and $500 \mathrm{~m}$, geotechnically related to $\mathrm{H} 2 \mathrm{~b}$. We observed that $\mathrm{H} 2$ was related to a low resistivity zone associated with confined hanging aquifers [3] and noted that the hydrated zone is not horizontal (profile A in Fig. 2), resulting in lateral anisotropy or permeability changes on the local scale. 

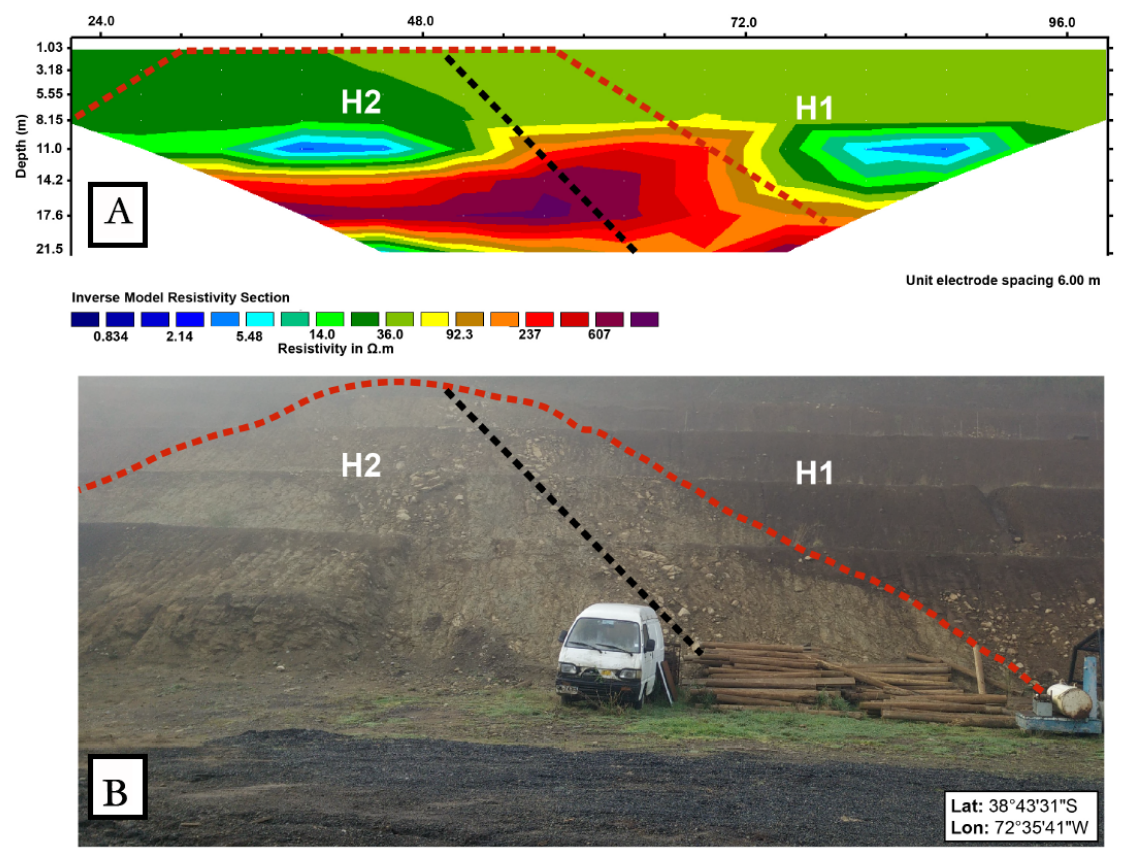

Figure 2. A) Resistivity inversion for the slope (derived from the ERT profile, Fig. 1). $\mathrm{H} 2$ is shown under dotted line. B) Measurement area. Highly (H2a) and partially $(\mathrm{H} 2 \mathrm{~b})$ weathered Pilmahue Formation is shown below the red line.

\section{Remote sensing}

Satellite data show shallow deformations of $20 \mathrm{~mm}$ in the direction of the line of sight (LOS) (Fig. 3), which can be divided into two stages. The first stage is deformation with null tendency during the period of march 2015 to september 2016. After september 16, subsidence began with both horizontal and vertical movement. The subsidence observed was a downhill slip stage consistent with the RIL indicators observed in the field. However, a period of null deformation is observed between march 2017 and july 2017, year. This may be associated with natural stabilization of the hillslope, prior to the months of intense precipitation in the area. After July 2017 subsidence started again, showing renewed destabilization of the hillslope. Precipitation data revealed events of over $40 \mathrm{~mm} /$ day on September 16. The reactivation of the hillslope occurred after a precipitation event of $40 \mathrm{~mm} /$ day on July 2017. This shows (Fig. 2) that the start of deformation is correlated with intense rainfall events. 


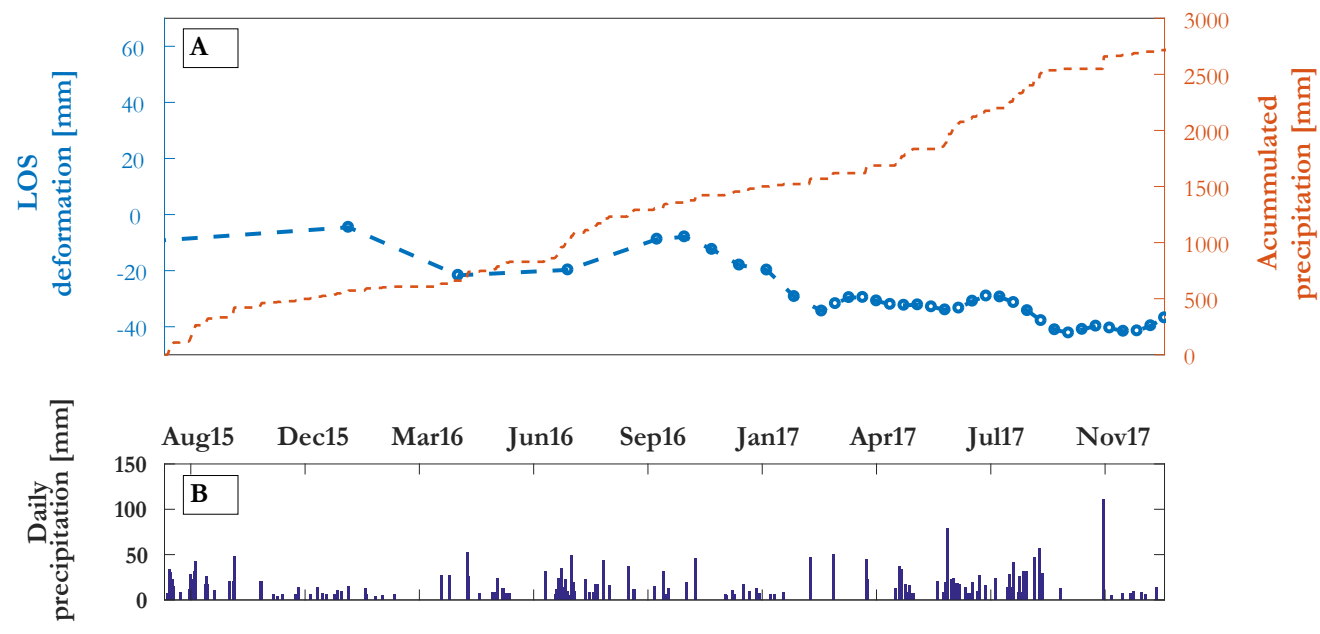

Figure 3. A) Surface deformation vs accumulated precipitation. Landslide reactivation detected after September 2016 with a trend of $40 \mathrm{~mm} / \mathrm{yr}$. B) Rainfall events. Both insets share the same temporal axis.

\section{Discussions}

Relation of superficial deformation with hydrometeorology

Deformation rates were estimated using the Interferometric SAR (InSAR) time-series technique. Our results showed deformation rates of $60 \mathrm{~mm}$ over three years, with variations after extreme precipitation events. We interpret these movements as slow RIL triggered by accumulated rainfall during 2016 (Fig. 3A). Active deformation was initiated in September 2016 due to instability of the hillslope. It should however be noted that the short period evaluated did not allow us to identify changes in deformation rates over extended time.

Likewise, our interferometric analysis was unable to identify the small RIL evaluated in the field in 2018. This is due to the small area covered and the abrupt change in coherence affecting the sensor in the temporal analysis. In the future we will extend the temporal deformation series, adding new SAR data such as ALOS, ASAR or CSK. For south central Chile, we suggest using acquisitions with greater spatial resolution to avoid the loss of coherence, capturing smaller slow landslide events.

\section{Implications of the internal composition}

Earlier geological mapping indicates the presence of a volcano-sedimentary unit composed of porphydic andesites, sandstones, and siltstones from the 
Pilmahue Formation (Fig. 4), dated ca $30 \mathrm{Ma}$ [31]. Soil development is due to weathering of this material by climatic conditions and introduced vegetation (Fig. 4A). The zone presents intense alteration, with clays generated by weathering of the rock and alterations of the texture and geochemical composition of the substrate (Fig. 2). These two factors have caused a reduction in effective porosity, resulting in low water infiltration indices in the substrate, and consequently high surface runoff.

Soil weathering is also affected by the high density of introduced flora, particularly Pinus radiata which now dominates central Chile. Thus, the texture and geochemical composition of the soil could trigger geo-mechanical instability due to the hydraulic properties of these minerals [23]. The geological structure of the area (Lanalhue Fault Zone) leads to areas of fracturing in response to fragile deformation, which in turn allows filtration to deep zones which could not occur through the lithology described above due to its low porosity. Remotely sensed data were complemented with ERT, allowing us to identify internal slope composition.

The observed low resistivity values at the bottom of the ERT profile (Fig. 2) may be correlated with local water infiltration inside the hillslope. We assume that this is seasonal resulting from the presence, below the low resistivity zone, of rock with low permeability that does not permit the continued infiltration of rainwater. Thus, we consider that water infiltration could vary seasonally, which is consistent with hanging aquifers [3]. Similarly, the presence of discontinous lateral confined aquifers appears to agree with our field observations. The ERT analysis was therefore consistent with the geological background and in situ observations.

We interpreted the resistivity value as clay with increased density. This might generate an overload due to accumulated precipitation (from rainfall measured by CHIRPS), consistent with previous studies [32]. Moreover, the clay zone presents a decrease in the internal friction angle when there is an increase in the water content during periods of heavy rain [3] with a generation of mudflow (Fig. 4C). Our interpretations agreed with the deformation analysis, showing shallow deformation at variable rates beginning after intense rainfall events (Fig. 3A and Fig. 4B).

\section{Potential and limitations}

Although our results could, per se, constitute a predictive model, we have also applied interdisciplinary integration in order to consider the geological and geotechnical characteristics (Fig. 4D). In particular, we 

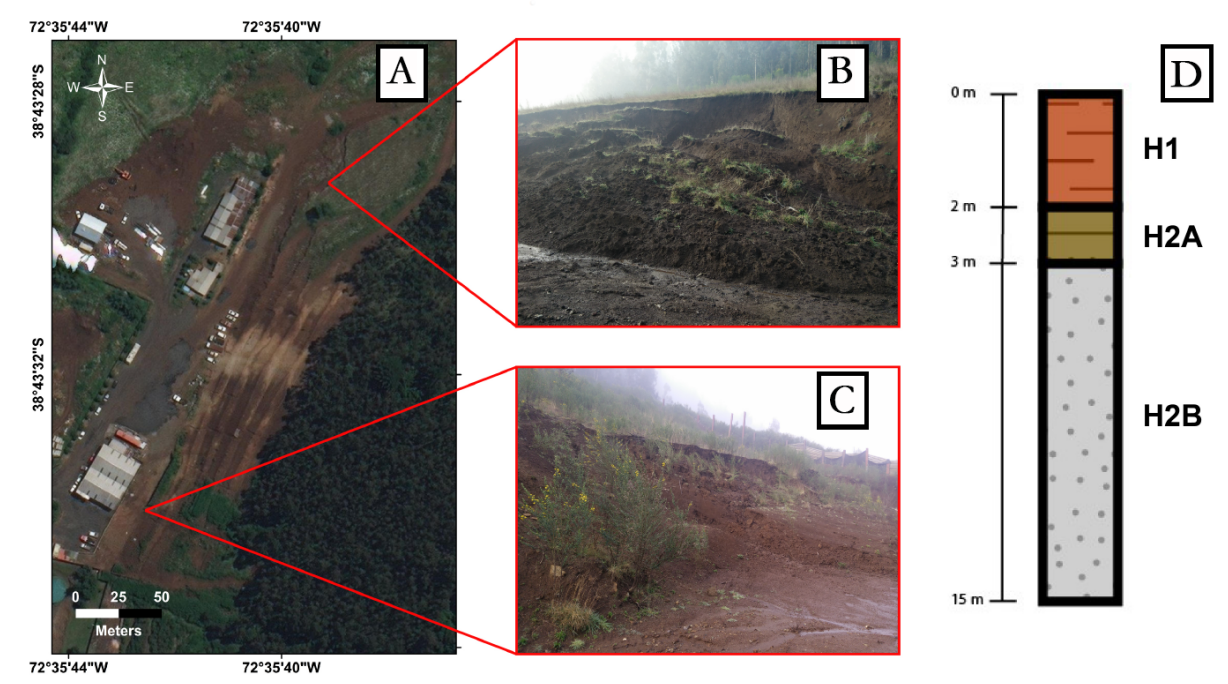

Figure 4. A) RIL event during 2018 (images from July, 2018). B) Landslide observed in June 2017. C) Mudflow observed in June 2017 D) Geotechnical model.

analyzed the lithology, soil type, and presence of structures (faults and fractures). The southern Andes possess classic unstable zones due to extreme hydrometeorological conditions; hence southern Chile could be susceptible to RIL due to volcanic soils in hillslopes [33].

RIL risk is increased by soil alteration due to chemical weathering caused by introduced flora, and could increase still further given the soil features identified by our study. In this respect, our study contributes to better understanding of the relation between volcanic soils and slow landslides. Several hillslopes could be at risk of RIL during extreme hydrometeorological events [34]. We evaluated their spatial/temporal deformation and related them to low permeability properties, reflected in the geoelectrical data (Fig. 2). Nevertheless, using satellite data it was not possible to observe a small RIL identified in situ. We recommend the use of alternative methodologies in the study zone, like FEM [35] or analytical models, to understand deformation rates.

Additional research is needed to understand the activation of small events, and how these results are related to weathering and soil moisture storage in hillslopes and clay. In the future, these results will support decision-making 
based on space geodetic data with respect to: infrastructure works near slopes and corrective actions to mitigate the effects of RILs. The InSAR results are not suitable for identifying causes or internal geometry.

\section{Conclusion}

We used an interdisciplinary methodology to evaluate an active RIL zone to understand and analyze the triggering role of hydrometeorological and geological conditions. To do so, we integrated hydrometeorological precipitation data, obtained in the infra-red band, with geotechnical and geophysical measurements taken in the field. These data were contextualized by estimating deformation rates from an InSAR time-series.

Our cross-discipline analysis revealed a slow landslide process occurring in the studied area, associated with hydrometeorological factors. Our results show that RILs occur after a period of intense rain in weathered volcanic to volcano-sedimentary soil, i.e. with important presence of clay material. The presence of cortical structures (faults) would help to trigger such processes. Our approach can be used to inform decision-making processes and to predict future events. Evaluating an active RIL is a challenge due to instrumental factors and the geological and compositional information about events. Interdisciplinary integration of different approaches enabled us to improve our interpretation of RILs.

We conclude from our results that these RILs events need to be integrated into administrative policies; however, more research is required before we can fully understand the spatial distribution of RILs events in the area. A better understanding of the dynamics of hillslopes will allow authorities to develop better mitigation plans and risk management.

\section{Acknowledgments}

We thank the three anonymous reviewers whose comments helped improve our manuscript. Deformation maps from InSAR data were developed by the DFP17-0014 and PII180008 projects projects. Field ERT survey were funded by DI18-0060 and FONDECYT 11180500 projects. Pablo Moreno-Yaeger holds an ANID international grant 72200330 . We appreciate the support of C. Torres, C. Salazar, C. Chiguailaf, and J. Oyarzun during field campaigns.

\section{Conflict of interest}

The authors have no conflict of interest to declare. 


\section{References}

[1] Anderson M. Landslide Risk Reduction in Developing Countries: Perceptions, Successes and Future Risks for Capacity Building. Landslide Science and Practice, Ed. Springer Berlin Heidelberg. 247-256, 2013.

doi: 10.1007/978-3-642-31313-4_32

[2] Kim HG, Lee DK, Park C. Assessing the cost of damage and effect of adaptation to landslides considering climate change. Sustainability, 10 (5): 1-22, 2018.

doi: $10.3390 /$ su10051628

[3] Vega JA, Hidalgo CA. Risk Assessment of Earthquake-Induced Landslides in Urban Zones. In Advancing Culture of Living with Landslides, Ed. Springer, 953-963, 2017.

doi: 10.1007/978-3-319-53498-5

[4] Harp EL, Reid ME, McKenna JP, Michael JA. Mapping of hazard from rainfall-triggered landslides in developing countries: examples from Honduras and Micronesia. Engineering Geology, 104 (3-4), 295-311, 2009.

doi: 10.1016/j.enggeo.2008.11.010

[5] Angeli MG, Pasuto A, Silvano S. A critical review of landslide monitoring experiences. Engineering Geology, 55 (3), 133-147, 2000 .

doi: 10.1016/s0013-7952(99)00122-2

[6] Kim HG, Lee DK, Park C. Assessing the cost of damage and effect of adaptation to landslides considering climate change. Sustainability, 10 (5): 1628, 2018.

doi: $10.3390 /$ su10051628

[7] Felizardo Batista E, De Brum Passini L, \& Christopher Morales Kormann A. Methodologies of Economic Measurement and Vulnerability Assessment for Application in Landslide Risk Analysis in a Highway Domain Strip: A Case Study in the Serra Pelada Region (Brazil). Sustainability, 11 (21), 6130, 2019.

doi: $10.3390 /$ su11216130 
[8] Fustos I, Abarca-del-Río R, Mardones M, González L, Araya LR. Rainfall-induced landslide identification using numerical modelling: A southern Chile case. Journal of South American Earth Sciences, 101: 102587, 2020.

doi: 10.1016/j.jsames.2020.102587

[9] Mansour MF, Morgenstern NR, Martin CD. Expected damage from displacement of slow-moving slides. Landslides, 8 (1): 117 131, 2011.

doi: $10.1007 /$ s10346-010-0227-7

[10] Fustos I, Remy D, Abarca-del-Río R, Muñoz A. Slow movements observed with in situ and remote-sensing techniques in the central zone of Chile. International Journal of Remote Sensing, 38 (24): 7514-7530, 2017.

doi: $10.1080 / 01431161.2017 .1317944$

[11] Bordoni M, Persichillo MG, Meisina C, Bartelletti C, Barsanti M, Avanzi, GD. Estimation of the susceptibility of a road network to shallow landslides with the integration of the sediment connectivity. Natural Hazards and Earth System Sciences, 18 (6): 1735-1758, 2018.

doi: 10.5194/nhess-18-1735-2018

[12] Heckmann T, Cavalli M, Cerdan O, Foerster S, Javaux M, Lode E, Smetanova A, Vericat D, Brardinoni F. Indices of sediment connectivity: opportunities, challenges and limitations. EarthScience Reviews, 187: 77-108, 2018.

doi: 10.1016/j.earscirev.2018.08.004

[13] Demaria EM, Maurer EP, Thrasher B, Vicuña S, Meza FJ. Climate change impacts on an alpine watershed in Chile: Do new model projections change the story?. Journal of Hydrology, 502: 128-138, 2013.

doi: 10.1016/j.jhydrol.2013.08.027

[14] Barros V, Field C, Dokken D, Mastrandrea M, Mach K, Bilir T, Chatterjee M, ..., White L. Climate change 2014: impacts, adaptation, and vulnerability. Part B: regional aspects. Contribution of working group II to the fifth assessment report of the intergovernmental panel on climate change. Cambridge: Cambridge University Press. 2014.

https://www.ipcc.ch/report/ar5/wg2/ 
[15] Sepúlveda SA, Petley DN. Regional trends and controlling factors of fatal landslides in Latin America and the Caribbean. Natural Hazards and Earth System Science, 15 (8): 1821-1833, 2015.

doi: 10.5194/nhess-15-1821-2015

[16] Handwerger AL, Fielding EJ, Huang MH, Bennett GL, Liang C, Schulz WH. Widespread initiation, reactivation, and acceleration of landslides in the northern California Coast Ranges due to extreme rainfall. Journal of Geophysical Research: Earth Surface, 124 (7): 1782-1797, 2019.

doi: 10.1029/2019JF005035

[17] Handwerger AL, Huang MH, Fielding EJ, Booth AM, Bürgmann, R. A shift from drought to extreme rainfall drives a stable landslide to catastrophic failure. Scientific reports, 9 (1): 1-12, 2019.

doi: $10.1038 /$ s41598-018-38300-0

[18] Garreaud RD, Boisier JP, Rondanelli R, Montecinos A, Sepúlveda HH, Veloso-Aguila D. The central Chile mega drought (2010-2018): a climate dynamics perspective. International Journal of Climatology, 40 (1): 421-439, 2019.

doi: 10.1002/joc.6219

[19] Terzaghi K. Theoretical Soil Mechanics. Chapman and Hali, Limited John Wiler and Sons, Inc, New York. 1944.

doi: 10.1002/9780470172766

[20] Yalcin A. The effects of clay on landslides: A case study. Applied Clay Science, 38 (1-2): 77-85, 2007.

doi: 10.1016/j.clay.2007.01.007

[21] Hungr O, Leroueil S, Picarelli L. The Varnes classification of landslide types, an update. Landslides, 11 (2): 167-194, 2014.

doi: $10.1007 /$ s10346-013-0436-y

[22] Cochachin A, Frey H, Huggel C, Strozzi T, Büech, E, Cui F, Flores A, Saito C. Integrated satellite InSAR and slope stability modeling to support hazard assessment at the Safuna Alta glacial lake, Peru. EGUGA2017-14505, 2017. 
[23] Strozzi T, Klimeš J, Frey H, Caduff R, Huggel C, Wegmüller U, Rapre AC. Satellite SAR interferometry for the improved assessment of the state of activity of landslides: A case study from the Cordilleras of Peru. Remote sensing of environment, 217: 111-125, 2018.

doi: $10.1016 /$ j.rse.2018.08.014

[24] Varnes DJ. Landslide hazard zonation: a review of principles and practice. United Nations International, Paris. 1984.

https://unesdoc.unesco.org/ark:/48223/pf0000063038

[25] Charrier R, Pinto L, Rodríguez M. Tectonostratigraphic evolution of the Andean Orogen in Chile. In Moreno T. y Gibbons W. (eds.) The Geology of Chile. The Geological Society, London. 21-114, 2007.

doi: $10.1144 /$ goch.3

[26] Mella M, Quiroz D. Geología del Área Temuco-Nueva Imperial, Región de La Araucanía. Servicio Nacional de Geología y Minería, Carta Geológica de Chile, Serie Geología Básica, 1 mapa escala 1:100.000. 122: 46, 2010.

http:/ / tienda.sernageomin.cl/TiendaVirtual2/ProductDetail. aspx?pid $=2268$

[27] Gunn DA, Chambers JE, Uhlemann S, Wilkinson PB, Meldrum PI, Dijkstra TA, Haslam E, Kirkham M, Wragg J, Holyoake S, Hughes PN, Hen-Jones R, Glendinning S. Moisture monitoring in clay embankments using electrical resistivity tomography. Construction and Building Materials, 92: 82-94, 2015.

doi: 10.1016/j.conbuildmat.2014.06.007

[28] Fustos I, Hermosilla M, Moreno-Yaeger P, Abarca-del-Río R. Solifluction and complex movements observed from InSAR time series and satellite precipitation products: Cases over central south of Chile. Conference: South America Water from Space, 1, 2018.

doi: $10.13140 /$ rg.2.2.14952.37122

[29] Kearey P, Brooks M, Hill I. An introduction to geophysical exploration, Ed. John Wiley \& Sons. 2013. 
[30] Sandwell DT, Myer D, Mellors R, Shimada M, Brooks B, Foster J. Accuracy and resolution of ALOS interferometry: Vector deformation maps of the Father's Day intrusion at Kilauea. IEEE Transactions on Geoscience and Remote Sensing, 46 (11): 35243534, 2008.

doi: $10.1109 / \operatorname{tgrs.2008.2000634~}$

[31] Ahmed R, Siqueira P, Hensley S, Chapman B, Bergen K. A survey of temporal decorrelation from spaceborne L-Band repeat-pass InSAR. Remote Sensing of Environment, 115 (11): 2887-2896, 2011.

doi: $10.1016 /$ j.rse.2010.03.017

[32] Galve J P, Pérez-Peña JV, Azañón JM, Closson D, Caló F, Reyes-Carmona C, ..., Herrera G. Evaluation of the SBAS InSAR service of the European space Agency's Geohazard Exploitation Platform (GEP). Remote Sensing, 9 (12): 1291, 2017.

doi: $10.3390 /$ rs9121291

[33] Zhao C, Kang Y, Zhang Q, Lu Z, Li B. Landslide identification and monitoring along the Jinsha River catchment (Wudongde reservoir area), China, using the InSAR method. Remote Sensing, $10(7): 993,2018$.

doi: $10.3390 /$ rs10070993

[34] Massonnet D, Souyris JC. Imaging with synthetic aperture radar, Ed. CRC Press. 2008.

[35] Funk C, Peterson P, Landsfeld M, Pedreros D, Verdin J, Shukla S, Husak G, Rowland J, Harrison L, Hoell A, Michaelsen J. The climate hazards infrared precipitation with stations: a new environmental record for monitoring extremes, Scientific data, 2 (1): 1-21, 2015.

doi: $10.1038 /$ sdata.2015.66 


\section{Evaluación de deslizamientos detonados por lluvias usando una aproximación interdisciplinaria}

Resumen: En gran parte de Suramérica, los deslizamientos de tierra lentos son detonados por condiciones hidrometeorológicas extremas que conducen, por ejemplo, a los llamados Deslizamientos Detonados por Lluvia (RILs). Estos RILs son comunes en áreas urbanas y tienen un impacto negativo en la población y en el desarrollo de infraestructura. A pesar de su importancia, estos eventos son pobremente entendidos todavía. Este estudio apuntó a la comprensión de la distribución espacial de los RILs en la zona urbana de Temuco, Chile $\left(38.8^{\circ} \mathrm{S}, 72.6^{\circ} \mathrm{W}\right)$. Esta área tiene las condiciones hidrometeorológicas típicas del sur de Chile. Se llevó a cabo la determinación por medio de un análisis temporal de deformaciones poco profundas, obtenido por medio interferometría de radar de apertura sintética (Sentinel 1 A/B). Estas tasas de deformación poco profunda se compararon con datos de precipitación obtenidos por satélite (producto CHIRPS) y tomografía de resistividad eléctrica (ERT). Se identificaron zonas propensas a RIL activas con tasas de deformación mayores a 60 mm durante el periodo de 2014 a 2017, lo cual apoya las teorías de control hidrometeorólogico. Se observaron movimientos lentos en suelos volcánico-sedimentarios lo cual sugiere la influencia de sus características geotécnicas. Los resultados se pueden extrapolar a los Andes australes $\left(35^{\circ} \mathrm{S}-43^{\circ} \mathrm{S}\right)$, donde un gran número de unidades volcánico-sedimentarias son susceptibles a RILs. Finalmente, la interacción de nuestra aproximación multidisciplinaria facilitará la comprensión de las dinámicas locales de los RIL, lo cual permitirá un mejor manejo del riesgo a los tomadores de decisiones de países suramericanos y otros en vía de desarrollo.

Palabras clave: InSAR; series de tiempo; deslizamientos de tierra inducidos por precipitación. 


\section{Avaliacao de deslizamentos provocados por chuvas usando uma aproximaçáo interdisciplinaria}

Resumo: Na maior parte da América do Sul, os deslizamentos lentos de terra são provocados por condições hidrometeorológicas extremas que conduzem, por exemplo, aos chamados Deslizamentos Provocados por Chuvas (RILs). Estes RILs são comuns em áreas urbanas e tem um impacto negativo na população e no desenvolvimento da infraestructura. Apesar de sua importância, estes eventos ainda são pobremente entendidos. Este estudo objetivou à compreensão das distribuições espaciais dos RILs na zona urbana de Temuco, Chile $\left(38.8^{\circ} \mathrm{S}, 72.6^{\circ} \mathrm{W}\right)$. Esta área tem as condições hidrometeorológicas típicas do sul do Chile. A determinação se realizou por meio de uma análises temporal de deformações pouco profundas, obtida por meio de interferometria de radar de abertura sintética (Sentinel $1 \mathrm{~A} / \mathrm{B}$ ). Estas taxas de deformação pouco profundas se comparam com dados de precipitação obtidas por satélites (produto CHIRPS) e tomografia de resistividade elétrica (ERT). Foram identificadas zonas propensas a RILs ativas com taxas de deformação maiores a $60 \mathrm{~mm}$ durante o período de 2014 a 2017, o qual apoia a teorias de controle hidrometeorológico. Observaram-se movimentos lentos em solos vulcânicos-sedimentários o que sugere a influência de suas características geotécnicas. Os resultados se podem extrapolar aos Andes austrais $\left(35^{\circ} \mathrm{S}-43^{\circ} \mathrm{S}\right)$, onde um grande número de unidades vulcânicas-sedimentarias são susceptíveis a RILs. Finalmente, a interação da nossa aproximação multidisciplinar facilitará a compreensão das dinâmicas locais dos RILs, o que permitirá um melhor gerenciamento do risco pelos tomadores de decisões de países Sul-Americanos e outros em desenvolvimento.

Palavras-chave: InSAR; series de tempo; deslizamentos de terra provocados por precipitações. 


\section{Dr. Ivo Fustos-Toribio}

Dr Fustos currently studies the relationship between Rainfall-Induced Landslides and climate change in the Andes cordillera. He is interested in a broad range of research lines such as remote sensing, volcanology and geophysical survey development. Their current research project is focused on understanding and develop new methodological assess tools for landslides in subduction zones (Andes and Himalaya).

ORCID: 0000-0002-3542-5477

\section{Geol. Pablo Moreno-Yaeger (ePhD)}

Pablo Moreno-Yaeger is a Graduate Student (MS/PhD) at the University of Wisconsin-Madison. His research area is volcanology and geochemistry focused on the Southern Volcanic Zone (Chile). He is studying how magmatic plumbing systems could be related to climate forces with geochronological and geochemical techniques. He has also worked with Chilean geoscientists studying mineralogy and petrological features in the Southern Chilean basement, where landslides processes are common.

ORCID: 0000-0001-5219-4546

\section{Geol. Daniel Vasquez}

Daniel Vásquez Antipán is a geologist at the Universidad Católica de Temuco (Chile). He currently develops new volcanological techniques at the Universidad de la Frontera in Chile, studying volcanoes of the Southern Andes. Furthermore, he is interested in volcanological studies related to magmatic plumbing systems and tectonics using geophysical techniques.

ORCID: 0000-0001-8106-4804 


\section{BSc. Bastian Morales}

Bastian Morales is a student of Geology (B. Sc. Geology) at the Catholic University of Temuco. His study area focuses on the geomorphological processes that occur in the southern Andes, associated with landslide processes.

ORCID: 0000-0002-7863-5503

\section{Dr. Antonieta Silva}

Dr Silva does research on applied physics with geophysical applications. Currently, she is a head laboratory at LiDAR laboratory in the Universidad de La Frontera.

\section{Dr. Elisa Ramírez}

Geologist and Doctor of Science mention Geology from the University of Chile, Chile. Postdoctorate at CICESE, México. Currently, she works as an instructor professor at the Catholic University of Temuco. Area of interest igneous and metamorphic petrology, clay minerals. Member of the Geokimun Research Center.

ORCID: 0000-0001-5900-432X 